Technical Papers

\title{
$\mathrm{LSR}$ 사출성형의 공정조건 변화가 캐비티 압력 및 성형품의 기계적 강도에 미치는 영향
} 박형필 $^{a *}$, 차백순 ${ }^{a}$, 이정원 $^{a}$, 고영배 $^{a}$, 김상권 $^{a}$, 정태성 $^{\mathrm{b}}$, 김동한 $^{\mathrm{c}}$, 이병옥 $^{\mathrm{c}}$

\section{Effects of Variation in Process Parameters on Cavity Pressure and Mechanical Strength of Molded Parts in LSR Injection Molding}

\author{
Hyung Pil Park ${ }^{\mathrm{a}^{*}}$, Baeg Soon Cha ${ }^{\mathrm{a}}$, Jeong Won Lee ${ }^{\mathrm{a}}$, Young Bae Ko ${ }^{\mathrm{a}}$, Sang Gweon Kim, \\ Tae Sung Jung ${ }^{\mathrm{b}}$, Dong Han Kimc, Byung Ohk Rhee \\ ${ }^{a}$ Molds \& Dies Technology R\&BD Group, Korea Institute of Industrial Technology, Incheon, 406-840, Republic of Korea \\ ${ }^{b}$ Department of Mechanical Design, Inha Technical College, Inchon, 402-752, Republic of Korea \\ ${ }^{c}$ Department of Mechanical Engineering, Ajou University, Suwon, 443-749, Republic of Korea
}

\begin{tabular}{|c|c|c|c|}
\hline \multicolumn{4}{|c|}{ ARTICLE INFO } \\
\hline \multicolumn{4}{|c|}{ Article history: } \\
\hline Received & 18 & March & 2014 \\
\hline Revised & 11 & April & 2014 \\
\hline Accepted & 14 & April & 2014 \\
\hline
\end{tabular}

Keywords:

LSR (Liquid silicone rubber)

Curing

Injection molding

Flash

Tensile strength

\begin{abstract}
Liquid silicone rubber (LSR) has been widely used in automotive, electrical, and medical components. Thus, research on the use of LSR in the injection molding process is required to obtain high-quality and high-performance products. In this study, a mold was fabricated to examine the effects of the process parameters on the molding and mechanical properties of LSR parts. A computer-aided engineering analysis was used to optimize the air vent depth and curing temperature to decrease the flash at the air vents caused by the low viscosity of LSR. Temperature and pressure sensors were mounted in the mold to determine the effects of the process parameters on the temperature and pressure in the cavity. The tensile strength of the LSR parts was also examined in relation to the process parameters.
\end{abstract}

\section{1. 서 론}

LSR (Liquid Silicone Rubber)는 친환경 열경화성 소재로서 진 동 특성, 수분에 대한 저항력, 고온에서 뛰어난 기계적 물성 및 내 열성을 갖고 있기 때문에 자동차, 전기전자 및 의료 부품 등의 고급 화 및 고기능화를 위해서 다양하게 이용되고 있다. 최근 LSR을 이용한 정밀 부품 개발이 활발해지며, 고품질화를 위한 LSR 사출 성형의 공정특성에 대한 연구가 요구되고 있다.

열가소성 플라스틱과 다르게 열경화성 LSR 수지는 액상의 주제 와 백금 촉매제가 함유된 경화제로 구성되어 있으며, 재료공급장치
에 의해서 일정비율로 혼합되어 고온의 금형 캐비티 내부로 주입된 다. 그러나 액상 상태의 LSR은 낮은 점도를 가지며, 사출성형 중 발생되는 전단율 변화 영향으로 캐비티 내부에 충전되는 LSR의 점도는 더욱 낮아진다. 낮은 점도의 LSR은 충전 과정 중 이젝터 핀 구멍 및 에어밴트와 같은 금형의 작은 틈새로 유입되어 플래쉬 불량을 발생시킨다. 또한 고온의 금형 캐비티로 주입된 LSR은 경 화반응을 거치며 체적 팽창이 발생된다. LSR의 체적변화는 잔류 응력의 발생을 의미하며, 경화온도가 높을수록 체적 변화는 크게 나타나기 때문에 기계적 물성 변화에 영향을 미친다. 따라서 LSR 사출성형은 외관품질 및 치수 정밀도 향상을 위한 금형 및 성형기

* Corresponding author. Tel.: +82-32-850-0326

Fax: $+82-32-850-0320$

E-mail address: php76@kitech.re.kr (Hyung Pil Park). 
술 확보와 더불어 부품의 고기능성 확보를 위한 공정변수 영향에 의한 기계적 물성 변화 분석이 필요하다 ${ }^{[1-5]}$.

본 연구에서는 LSR의 공정조건 영향에 따른 성형 특성을 알아 보고 기계적 물성을 평가하기 위한 금형을 제작하였으며, LSR의 낮은 점도 영향으로 발생되는 에어밴트 부의 플래쉬 발생 저감을 위해서 에어밴트 깊이와 경화온도가 미치는 영향을 해석적으로 분 석하여 적용하였다.

또한 LSR 인장시험 금형 내부에 온도와 압력센서를 설치하여 공정조건 변화에 따른 캐비티 내의 압력 및 온도 변화와 기계적 강도 변화를 분석하였다.

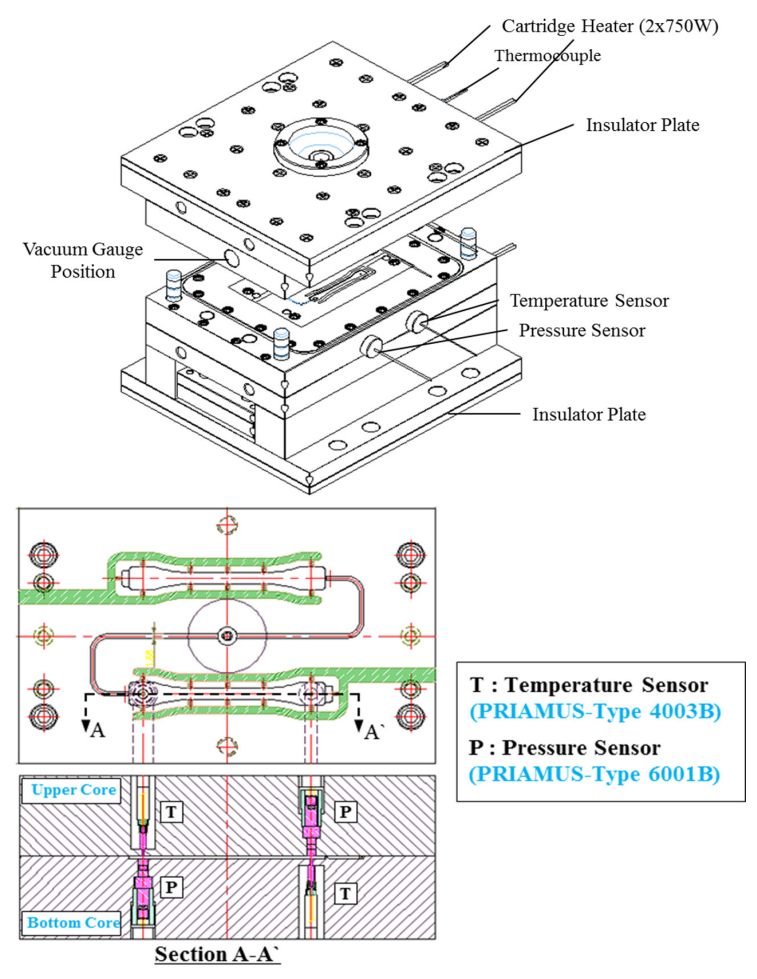

Fig. 1 Location of temperature and pressure sensors

\section{LSR 인장시험 금형 설계}

LSR 사출성형의 공정조건 영향에 따른 기계적 물성을 평가하기 위해서 ISO 3167 규격의 인장시편 금형을 설계하였으며, Fig. 1에 나타낸다. LSR의 경화를 위한 고온의 금형 온도 형성을 위해서 상, 하측에 $750 \mathrm{~W}$ 의 카트리지 히터를 장착하였다. 또한 LSR 성형 특성 분석을 위해서 게이트와 캐비티 충전 말단 에 압력센서와 온 도센서를 각각 설치하였다.

\section{1 에어밴트의 플래쉬(Flash) 발생 분석}

일반적으로 사출금형은 수지가 충전되며 캐비티 내에 갇힌 공기 를 원활히 배출하고, 충전말단부의 단열 압축에 의한 탄화현상 및 사출압력 상승을 방지하기 위해서 에어밴트를 설치한다. 캐비티 내 부의 갇힌 공기를 원활히 배출하기 위해서는 에어밴트의 깊이가클 수록 효과적이지만, 성형과정 중 수지가 유입되어 플래쉬를 발생시 킨다 ${ }^{[6]}$. 일반적으로 에어밴트 깊이는 열가소성 플라스틱의 경우 $0.015 \sim 0.03 \mathrm{~mm}$ 를 적용하며, 상대적으로 더욱 낮은 점도를 갖는

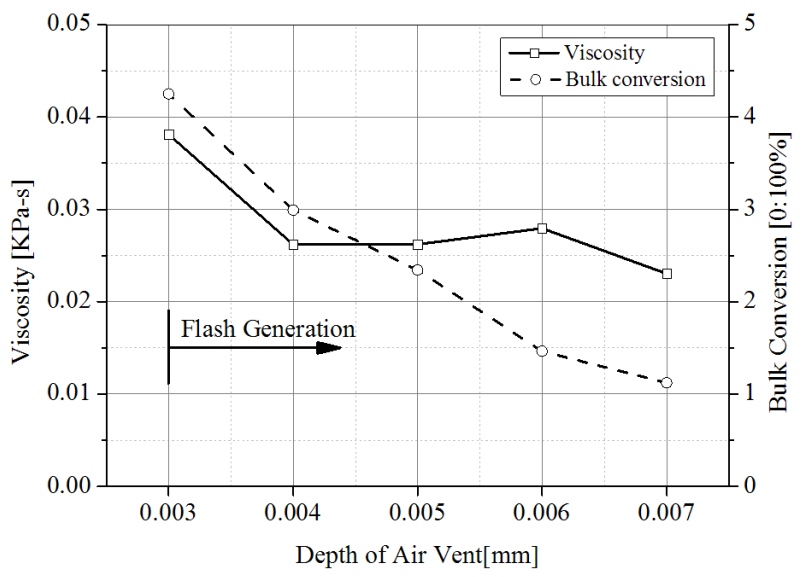

Fig. 3 The effects of air vent depth on viscosity and bulk conversion

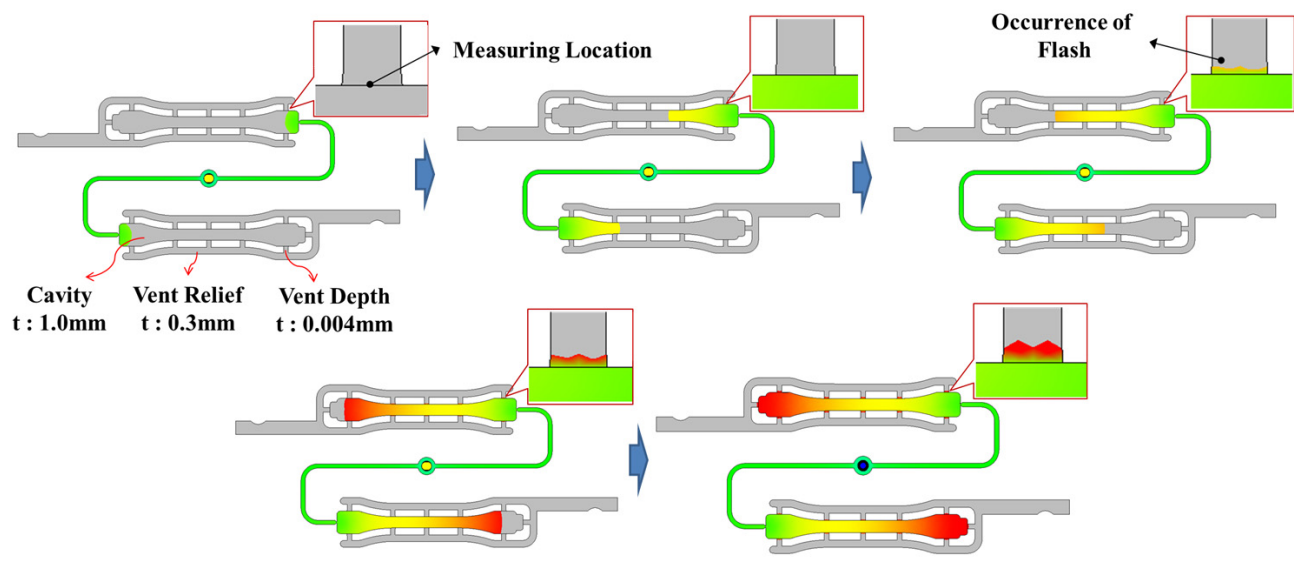

Fig. 2 Flow pattem of LSR tensile specimen model 
열경화성 LSR은 0.004 0.005 mm를 적용하고 있다. 따라서 권 장된 에어밴트 깊이의 LSR 인장시험 금형에 적용 가능성을 사출 성형해석을 통하여 분석하였다 ${ }^{[7]}$.

사출성형해석에는 Autodesk Moldflow Insight (AMI 2012) 소프트웨어를 사용하였으며, LSR 재료는 모멘티브사의 Silopren LSR 3386/40에 대한 점도 데이터가 없기 때문에 유사한 점도를 갖는 다우코닝의 SILASTIC LC 70-2004를 적용하였다. Fig. 2는 금형온도 $175^{\circ} \mathrm{C}$, 수지온도 $20^{\circ} \mathrm{C}$, 경화온도 $170^{\circ} \mathrm{C}$, 경화시간 30 초, 사출시간 1 초에 대한 LSR 인장시험 금형의 충전과정을 나타내고 있으며, 플래쉬의 발생을 확인할 수 있다.

LSR 수지가 게이트를 통과한 후 초기 충전 중에는 플래쉬 발생 영향이 나타나지 않지만, 충전이 진행되며 사출압력의 상승으로 플 래쉬가 점차 성장되고 있음을 알 수 있다. 또한 충전 완료 시점에 이르러 보압의 영향으로 플래쉬 발생이 더욱 크게 나타남을 볼 수 있다. Fig. 3은 Fig. 2의 에어밴트 측정 위치에서 에어밴트 깊이 $(0.003 \mathrm{~mm} \sim 0.007 \mathrm{~mm})$ 변화에 따른 LSR의 점도 변화와 경화율 (Bulk Conversion)에 대한 해석결과를 나타내고 있다. 에어밴트 깊이가 작을수록 점도가 높게 형성됨을 볼 수 있다. 이는 충전된 LSR 수지가 에어밴트부로 유입되지 않고 경화되어 플래쉬가 형성 되지 않음을 의미하며, 경화율 역시 높아지는 결과를 보였다. 이를 통하여 플래쉬 발생의 방지를 위해서 에어밴트 깊이 $0.003 \mathrm{~mm}$ 이하가 효과적임을 알 수 있다.

\subsection{LSR 인장시험 금형의 가열 특성 평가}

LSR 사출성형은 상온의 LSR 재료를 금형 내 캐비티로 주입하 여 정해진 시간 동안 열을 가하여 재료 내에 함유된 백금촉매제에 의한 경화반응을 거쳐 제품을 성형한다. 따라서 LSR의 경화반응 을 위한 금형온도는 제품의 품질 및 성형사이클을 결정짓는 중요 공정변수이다 ${ }^{[8]}$. 그러나 LSR 인장시편 금형은 상하측 플레이트에 설치된 카트리지 히터로 캐비티와 코어를 열전달을 통하여 가열하 기 때문에 금형가열 시 금형 표면의 목표 온도 도달에 요구되는 승온시간, 금형내 삽입된 온도센서를 통한 온도제어 정확성, 제품 성형부 캐비티의 균일온도 분포 등의 정확한 분석이 요구된다.

LSR 인장시편 금형이 성형 온도에 이르는 예비 가열 시간을 예 측하고, 금형과 성형면의 열적 안정성을 평가하기 위하여 과도상태 열전달(transient thermal) 해석을 수행하였다. 열전달 해석은 상 용 해석 프로그램인 ANSYS Workbench V.13을 사용하였으며, 히터가 설치된 4 개의 구멍 면에 각각 $750 \mathrm{~W}$ 의 열원을 인가하였고, 단열판이 설치된 면을 제외한 금형의 노출면에는 자연 대류 $\left(5 \mathrm{e}-6 \mathrm{~W} / \mathrm{m}^{2{ }^{2} \mathrm{C}}\right)$ 에 의한 열의 손실이 발생하는 것으로 가정하였다.

Fig. 4는 LSR 인장시편 금형의 온도 분포를 보여주고 있다. 금 형의 상측에 비하여 하측의 중량이 크므로 상대적으로 낮은 온도를
보이고 있음을 확인 할 수 있다. Fig. 5 는 캐비티와 코어 면의 온도 분포를 보여주는데, 해석에서 성형면의 온도 분포는 상하측 모두 $1^{\circ} \mathrm{C}$ 이내의 낮은 차이를 보였다.

따라서 Fig. 6와 같이, 금형 가열 시의 실제 표면 온도 범위를 파악하기 위하여 측정을 수행하였다. 측정에 사용된 장비는 NI사 의 Compact DAQ (Thermocoulpe Module)로 측정 온도를 1초 에 3개씩 실시간으로 받아들이며, 측정에 사용된 Thermocoulpe은 $\mathrm{K}$ 타입, 그리고 온도측정에 사용한 소프트웨어는 Signal Express (Labview 8.2)를 이용하였다.

Fig. 7은 금형 상하측의 표면온도를 측정한 결과로써, Fig. 7(a) 상측 금형의 경우 표면온도가 목표온도 보다 약 $10^{\circ} \mathrm{C}$ 낮게 유지되 었다. 이는 가열히터 제어를 위해서 삽입된 온도센서가 금형과 정 확하게 접촉하지 못하여 나타나는 결과로 판단된다. 반면에 Fig. 7(b) 하측금형의 경우 목표온도 보다 약 $4^{\circ} \mathrm{C}$ 높게 형성되었다. 따

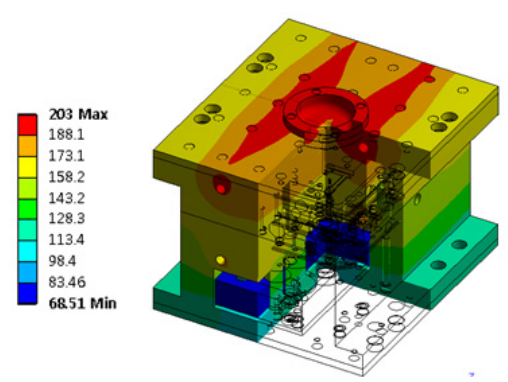

Fig. 4 The predicted temperature distribution of the LSR mold

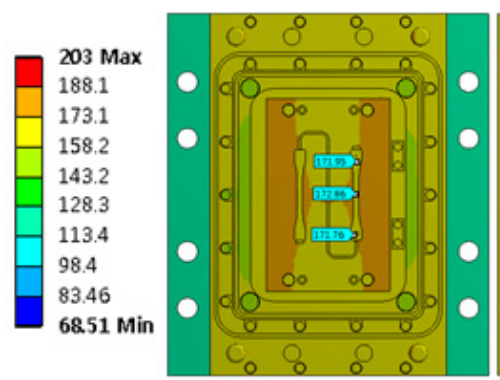

(a) Core

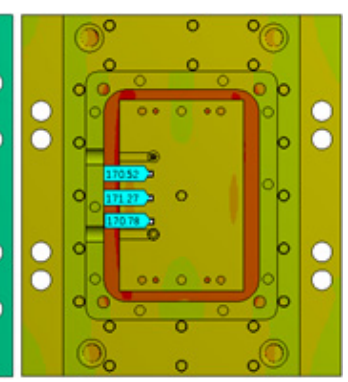

(b) Cavity
Fig. 5 Temperature distribution for core and cavity surface

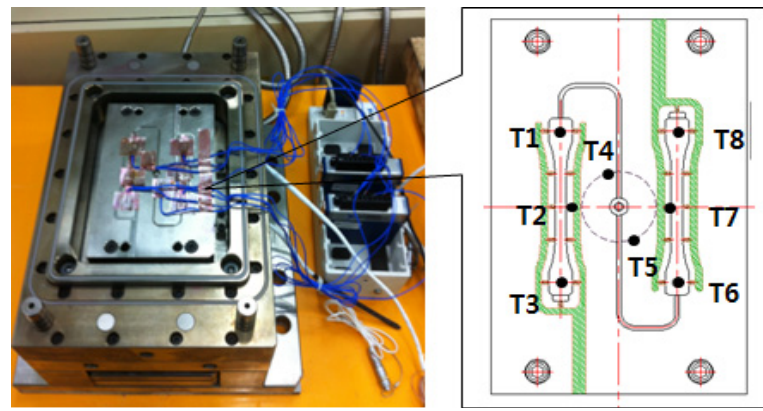

Fig. 6 Temperature measurement location on mold surface 


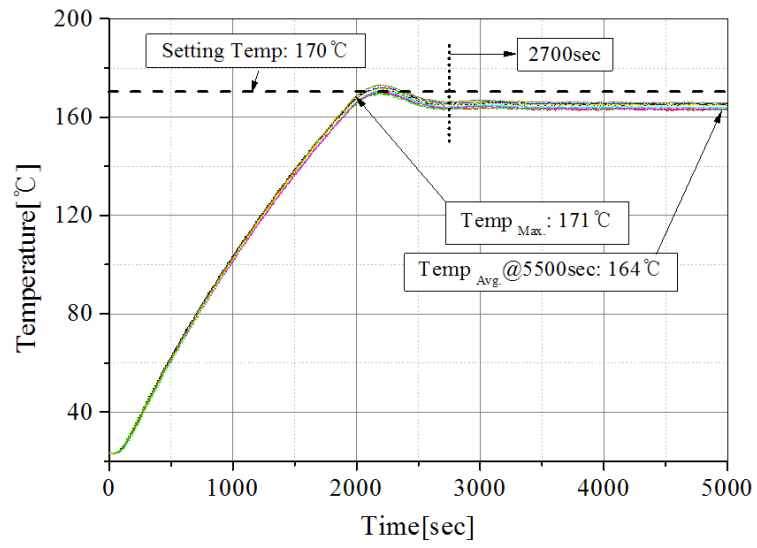

(a) Upper mold

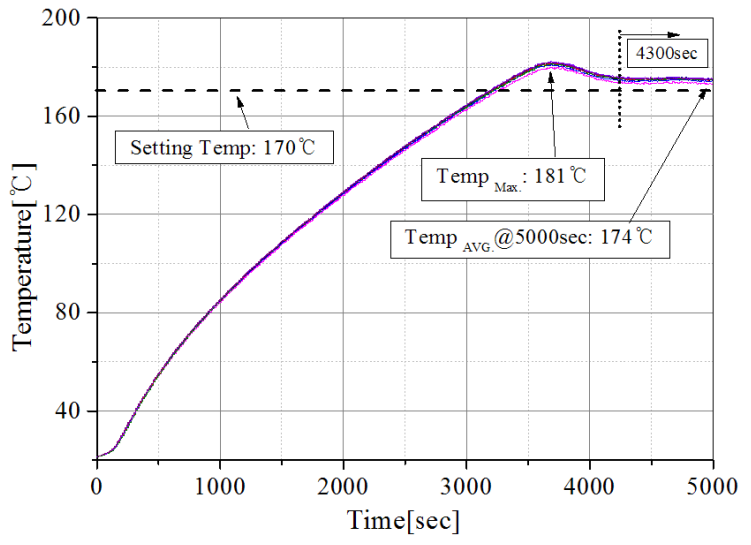

(b) Lower mold

Fig. 7 Temperature profiles on mold surface during heating

라서 $\mathrm{LSR}$ 인장시험 금형을 $170^{\circ} \mathrm{C}$ 로 가열하기 위해서는 상측은 $180^{\circ} \mathrm{C}$, 하측은 $166^{\circ} \mathrm{C}$ 로 설정해야 하며, 상하측의 목표온도 도달시 간을 고려하여 초기 가열시간은 70 분 이상 요구됨을 알 수 있다.

\section{3. 공정조건에 따른 온도와 압력 변화}

\section{1 금형온도 측정 결과}

캐비티 압력 및 온도센서를 이용하여 주요 공정 조건 중 사출속 도, 보압, 경화온도, 경화시간 변화에 따른 캐비티 압력 및 온도 변화를 분석하였다. 실험에는 모멘티브사의 Silopren LSR 3386/40 재료를 적용하였으며, Engel 의 110톤 LSR 사출성형기를 사용하 였다. Fig. 8은 금형온도 $180^{\circ} \mathrm{C}$, 경화시간 25 초를 적용하였을 때 측정된 캐비티 내 압력 및 온도 결과이다.

Fig. 8(a)에 보듯이, 고온의 금형 내로 상온의 LSR이 주입되어 캐비티에 설치된 온도센서에 도달하면 온도가 급격히 떨어지는 현 상이 나타나며, 고온의 금형으로부터 전달되는 열에 의해서 LSR 은 온도가 증가한다. 캐비티 압력은 LSR 충전이 이뤄지며 경화에 의한 점도 상승 및 유동저항 영향으로 증가되며, 보압에 의한 급격

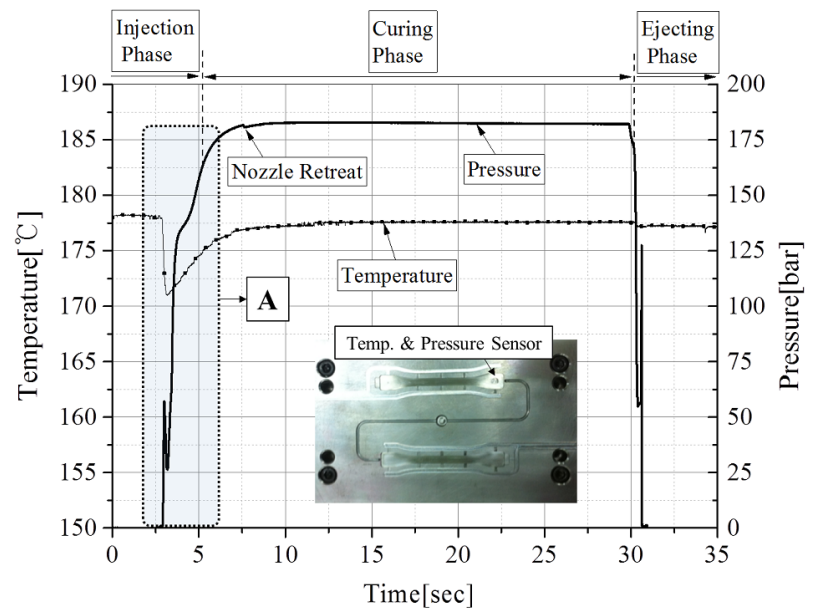

(a)

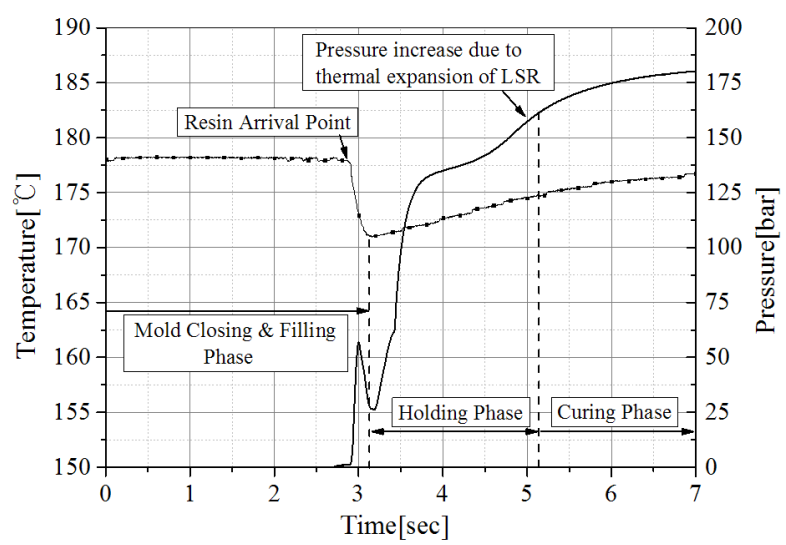

(b)

Fig. 8 Photo of (a) Pressure and temperature profiles in cavity and (b) enlarged portion of the profiles

한 압력 상승이 나타난다. 이후 좁은 게이트의 경화가 완료되면서 보압력의 전달이 낮아져 압력 증가는 미비하게 나타난다. Fig. 8(b) 에 보듯이, 캐비티 내부에 충전 완료된 LSR은 경화반응으로 발생 되는 체적 팽창 영향으로 압력의 2차 상승 현상이 발생되었다.

\section{2 사출속도 및 보압에 따른 압력 변화}

일반적으로 LSR의 낮은 점도는 빠른 사출속도를 적용할 경우 사출압력의 증가 영향으로 플래쉬가 발생되므로 낮은 사출속도를 적용한 제품 성형을 권장하고 있다. 따라서 사출속도 $10,15,20$ $\mathrm{mm} / \mathrm{s}$ 의 낮은 사출속도 범위에 대한 실험을 진행하였으며, Fig. 9 는 사출속도에 따른 $\mathrm{LSR}$ 의 게이트 통과 시 캐비티 압력이다. 사출 속도가 빠를수록 압력이 증가되었으며, 특히 사출속도가 $20 \mathrm{~mm} / \mathrm{s}$ 인 경우에는 LSR의 낮은 점도 영향으로 설정된 보압절환 위치에 서 정확한 제어가 이뤼지지 못하여 급격한 압력상승이 발생되었다.

이는 빠른 사출속도 적용 시 LSR 사출성형의 보압절환 제어가 어려움을 의미한다. 


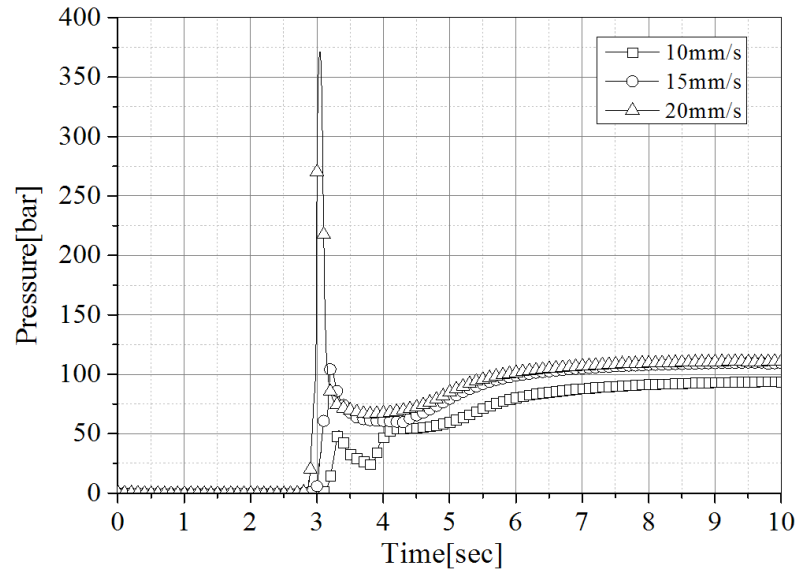

Fig. 9 Effect of injection speed on cavity pressure

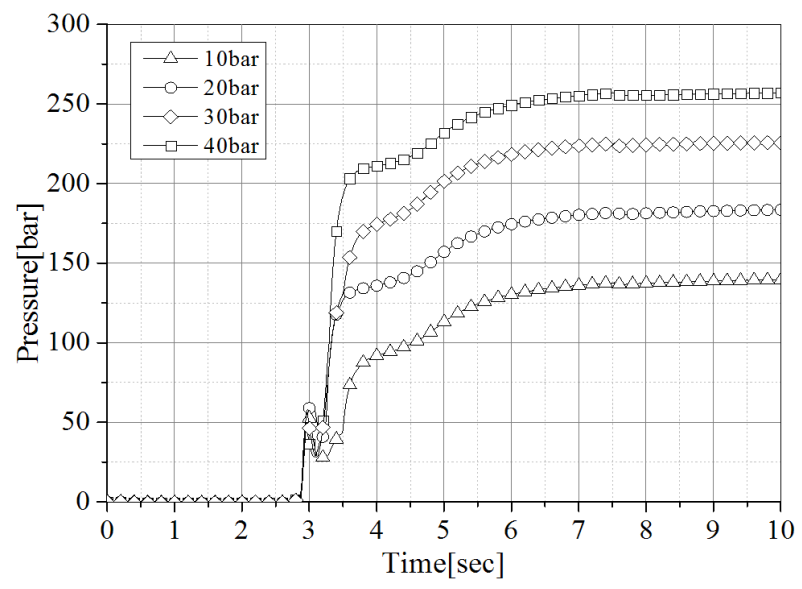

Fig. 10 Effect of packing pressure on cavity pressure

열가소성 플라스틱의 체적 수축 보상을 위한 보압공정과 다르게, LSR 사출성형에서 보압의 역할은 낮은 점도의 LSR 수지가 캐비 티 내부에 충전된 후 경화반응이 완료될 때까지 체적 팽창에 의한 게이트 역류현상을 방지하기 위해서 적용한다. Fig. 10은 보압을 $10 \mathrm{bar} \sim 40 \mathrm{bar}$ 로 변화시켰을 때의 캐비티 압력 변화를 나타내고 있다. 보압 증가에 따라 캐비티 압력이 증가되는 결과를 보였으며, 높은 보압에 의한 플래쉬 방지 및 역류 현상의 방지를 고려하여 LSR 인장시험 금형의 적정 보압은 $20 \sim 30 \mathrm{bar}$ 이내로 판단된다.

\section{3 경화온도 및 경화시간에 따른 압력 변화}

Fig. 11 은 동일 성형조건하에서 경화온도를 $155^{\circ} \mathrm{C}, 180^{\circ} \mathrm{C}, 20$ $5^{\circ} \mathrm{C}$ 변화 하였을 때의 캐비티 압력 변화이다. 빠른 경화특성을 갖 는 LSR은 온도가 높아짐에 따라 유동전달시스템을 통과하며 발생 되는 경화반응이 빠르게 진행되어 $\mathrm{LSR}$ 의 충전 중 점도 상승을 유 발하여 사출압력이 높아지는 현상이 나타났다. 또한 경화온도가 높 을수록 체적 팽창이 더욱 크게 나타나기 때문에 캐비티 압력이 증

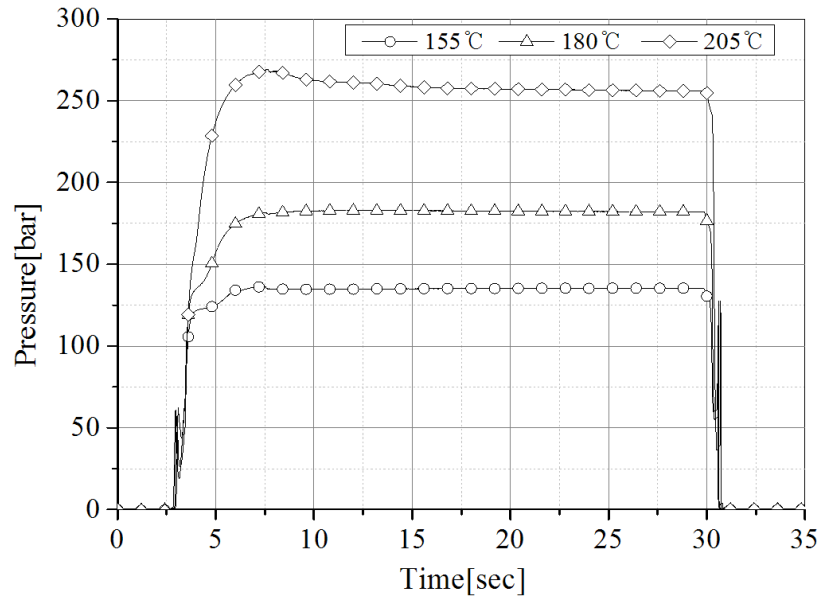

Fig. 11 Effect of curing temperature on cavity pressure

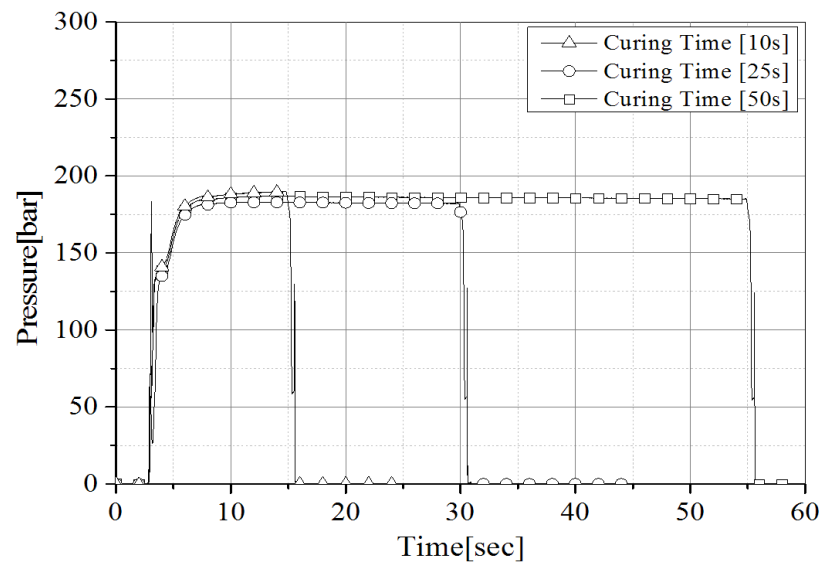

Fig. 12 Effect of curing time on cavity pressure

가되었다.

따라서 이와 같은 이유로 사출속도 및 보압 조건은 경화온도에 따라 변화가 필요하다. Fig. 12는 경화시간에 따른 캐비티 압력 변 화이며, 경화온도와 다르게 경화시간은 캐비티 압력 변화에 영향을 미치지 않았다.

\section{4. 공정조건에 따른 기계적 강도 분석}

경화온도에 의한 사출압력의 변화는 체적 변화를 의미한다. Song의 연구에 따르면 LSR 경화에 의한 체적 팽창과 이형된 이후 의 냉각에 의한 수축현상은 LSR내부의 잔류응력을 형성하며, 경 화온도가 높을수록 잔류응력이 높아진다는 연구 결과를 발표하였 다 ${ }^{[9]}$. 이는 경화온도의 영향으로 기계적 물성이 변화될 수 있음을 의미한다.

따라서 경화시간 25 초에서 경화온도 $155^{\circ} \mathrm{C}, 180^{\circ} \mathrm{C}, 205^{\circ} \mathrm{C}$ 로 변 화될 때 LSR의 기계적 물성에 미치는 영향을 분석하였다. 각 조건 


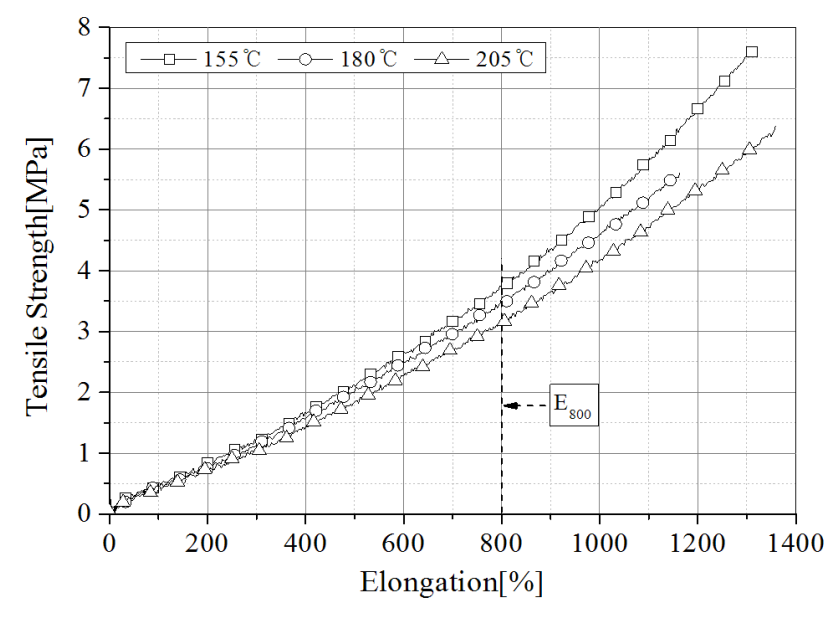

Fig. 13 Effect of curing temperature on tensile strength
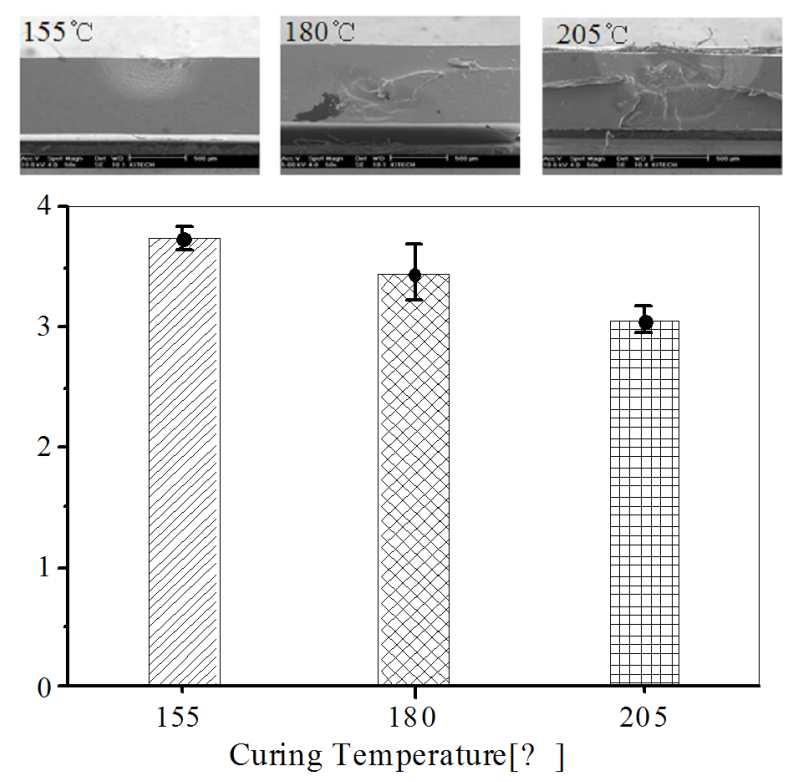

Fig. 14 Comparison with LSR tensile strength at $800 \%$ of strain rate and SEM image of tensile fracture surface

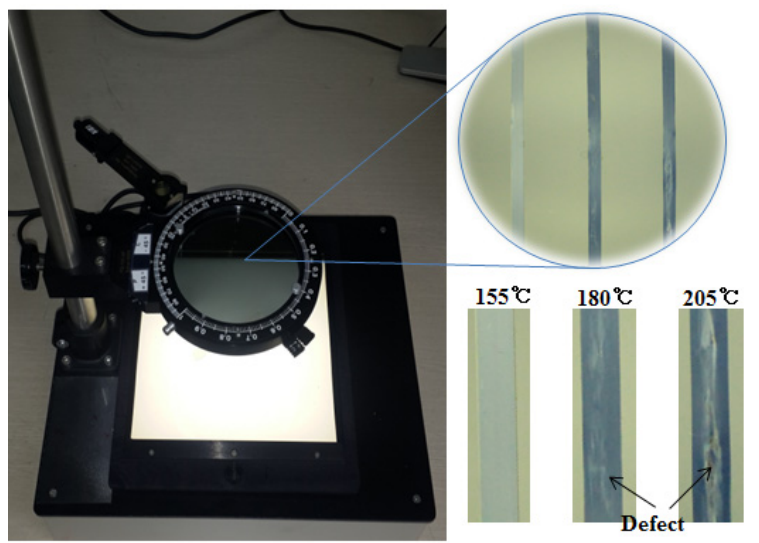

Fig. 15 Measurement of stress distribution by effect on curing temperature
당 3개의 샘플은 ASTM D412규격에 따라 KNR System의 고분 자 인장시험기를 이용하여 $500 \mathrm{~mm} / \mathrm{min}$ 속도로 인장시험을 수행하 였으며, 각각의 측정된 인장강도를 비교 분석하였다. 그러나 LSR 은 높은 탄성 특성 영향으로 항복점이 불분명하기 때문에 인장강도 비교가 어렵다. 이러한 영향으로 고무와 같은 고탄성 재료는 강성 비교의 척도로 일정 연신율을 부여하는데 필요한 인장강도를 비교 한다. 따라서 Fig. 13과 같이, 본 연구에서도 LSR의 높은 연신특 성을 고려하여 연신율 $800 \%$ 에 대한 인장강도를 비교하였다.

Fig. 14 는 경화온도와 경화시간에 따른 연신율 $800 \%$ 시점의 인 장강도 비교 결과와 인장시편 파단면에 대한 $\mathrm{SEM}$ 측정 결과이다. 동일한 연신율에서 경화온도가 높아질수록 인장강도는 낮아졌으 며, 이는 동일한 인장응력이 걸렸을 때 연신율이 증가되는 결과를 보였다. 이는 경화온도의 영향으로 발생되는 잔류응력 영향과 LSR 의 물성변화 영향이 복합적으로 나타난 결과로 사료된다.

Fig. 15는 경화온도별로 인장시편을 일정거리 만큼 연신한 후에 형성되는 스트레스 분포이다. 측정에는 Strainoptics사의 PS-100-SF POLARIMETER를 사용하였다. 경화온도가 높을수록 잔류 스트 레스 영향은 크게 나타났다. 특히 경화온도가 높아질수록 러너를 통과하는 LSR의 유동선단부가 이미 경화되고, 경화된 LSR이 캐 비티 내부에 충전되어 성형품에 결함으로 나타났다. 이러한 이유로 Fig. 14의 경화온도별 파단면 형상이 다르게 나타난 것이며, 기계 적 강도변화에도 영향을 미치는 것으로 판단되었다.

\section{5. 결 론}

본 연구에서는 LSR의 공정조건 영향에 따른 성형 특성 및 기계 적 물성 평가를 위한 인장시험 금형의 가열 특성을 분석하여 성형 면의 온도불균형과 가열시간을 도출하였으며, 사출성형해석을 통 하여 LSR 금형의 플래쉬 발생을 방지하기 위한 적정 에어밴트 깊 이 $(0.003 \mathrm{~mm})$ 를 도출하였다. 제작된 LSR 인장시험 금형으로 공 정조건 변화에 따른 캐비티 압력 변화를 분석하여 느린 사출속도와 20 30 bar의 보압, 그리고 경화온도가 캐비티 압력 변화에 영향 을 미치며, 특히 LSR의 경화 시 체적 팽창의 영향으로 캐비티 내압 의 2 차 상승이 나타남을 확인할 수 있었다. 또한 LSR 인장시편의 인장강도 분석을 통하여 높은 경화온도가 인장강도 변화에 영향을 미치며, 이는 LSR의 체적 변화에 의한 잔류응력과 높은 경화온도 로 인한 물성저하가 복합적으로 나타난 결과로 판단하였다. 본 연 구의 LSR 금형, 성형특성 및 기계적 물성 등의 결과는 향후 LSR 금형 개발을 위한 기술적 자료로 활용될 수 있을 것으로 판단된다. 


\section{후기}

이 연구는 산업통상자원부의 산업원천기술 개발 사업[방수제품 용 복합 열가소성/열경화성 이종소재 정밀사출 금형 기술개발]의 지원으로 수행되었으며, 이에 감사드립니다.

\section{References}

[1] Haberstroh, E., Michaeli, W., Henze, E., 2002, Simulation of the Filling and Curing Phase in Injection Molding of Liquid Silicone Rubber (LSR), J. Reinf. Plast. Comp. 21 461-470.

[2] Tarinee, N., Polchit, B., 2006, The Effect of Curing Parameters on the Mechanical Properties of Styrene-NR Elastomers Containing Natural Rubber-Graft-Polystyrene, J. Kasetsart. 40 7-16.

[3] Rahul, J., Simranpreet, S. G., 2012, Optimization of Vulcanization Process in Windshield Weather Rubber Strip Application, Int. J. Adv. Eng. Tech. 3 67-71.
[4] Rey, T., Chagnon, G., Cam, J.-B., Favier, D., 2013, Influence of the temperature on the mechanical behaviour of filled and unfilled silicone rubbers, Poly. Test.. 32 492-501.

[5] Yuanxiang, Z., Jianyi, W., Haihang, C., Qiong, N., Qinghua, S., Yunshan, W., 2009, The Influence of Pre-stressing on Breakdown Characteristics in Liquid Silicone Rubber J. Electro. 67 422-425.

[6] Menges, G., Michaeli, W., Mohren, P. 2000, How to Make Injection Molds, HANSER, USA

[7] Rubber Fabrication Solutions, 2001, Injection Moulding of SILASTIC Liquid Silicone Rubber, Dow Corning Corporation.

[8] Lee, S., Kang, J. J., Lee, J., Hong, S. Ko, J. S., Lee, J., Noh, J., 2012 , Silicone Injection Mold \& Molding Technology for Super-hydrophobic Curved Surface J. Kor. Soc. Prec. Eng. 29 13-18.

[9] Song, M., Kim, H., Kang, J., Kim, K., 2011, Finite Element Analysis of Residual Stress Evolution during Cure Process of Silicone Resin for High-power LED Encapsulant, J. Kor. Soc. Prec. Eng. 28 219-225. 